\title{
Economic Assessment of Changes in the Regulation of the Transmission Activity in Colombia
}

\author{
Andrés Andrade-Becerra ${ }^{1}$, Sergio Marenco-Rua ${ }^{1}$, John-William Grimaldo-Guerrero ${ }^{2, *}$, Eliana-Maria \\ Noriega-Angarita ${ }^{2}$ and Jorge-Ivan Silva-Ortega ${ }^{2}$
}

${ }^{1}$ Electrical Engineering, Universidad de la Costa, Barranquilla, Colombia.

${ }^{2}$ Department of Energy, Universidad de la Costa, Barranquilla, Colombia.

Received 14 June 2019; Accepted 20 December 2019

\begin{abstract}
The research presents an analysis of the technical, legal and economic implications generated due the change in regulating for the remuneration of the electricity transmission sector in Colombia. Economic comparisons are made of the existing and the proposal methodology by the regulatory authority in the electricity sector in Colombia. The results allow to identify the technical-economic impact generated in the companies of the transmission sector and to the users. Finally, it can be concluded that the change in remuneration will not affect the returns of investment in companies and will encourage the improvement of their electric assets and the quality of service.
\end{abstract}

Keywords: Electricity, Regulation, Revenue, Transmission.

\section{Introduction}

The National Interconnected System (NIS) is the infrastructure that allows the electric power to be carried long distances from the generation points; its planning and growth is of vital importance for the expansion of the generation system, bringing the service to non-interconnected zones and improving the reliability of the service $[1,2,3]$.

The National Transmission System (NTS) of Colombian is built in its entirety throughout the mountainous region, it has international interconnections with Ecuador and Venezuela [4], and it has approximately $15223.88 \mathrm{~km}$ of transmission networks [5]. The NTS began in 1967, with the creation of the company Interconexión Eléctrica S.A. (ISA), responsible for the construction, maintenance and administration of the transmission network [6].

The transmission activity is considered as a natural monopoly [7], due to the technical-economic inefficiency when there are two or more operators in a defined geographical area; currently in Colombia there are 16 registered companies that carry out the transmission activity [8], one of them, ISA owns $77.18 \%$ of the network's activities [9], at the beginning ISA was the state company in charge for the construction of the transmission system and due to the reform of the electricity market with the law 142 of 1994 and 143 of 1994, the guarantee of exceeding participation limits was given [10].

The projects of the electricity sector are proposed by the Unidad de Planeación Minero Energética (UPME), Energy Mining Planning Unit, they are offered by public auction seeking the greatest benefit for users [11]; in the case of transmission sector, projects that do not have bidders and be necessary will be awarded to the company ISA [12], likewise, ISA must present a proposal for each of the projects defined in the calls [13], increasing the participation in the transmission sector.

The electricity sector is regulated by Comision de Regulación de Energía y Gas (CREG) [14], Energy and Gas Regulatory Commission, the Law 143 assigned it the function of establishing the methodology for the calculation of the tariffs for the use of electricity networks [12, 15], under a model of free competition [16], these payments are collected on the electricity bill of end users.

The Colombian NTS is presenting faults such as low voltages, overloads in transformation assets, exhaustion of transformation capacity and radial connection in some areas of the NIS [3]. The departments in the north of Colombia are the most affected due to the depletion in the transformation capacity of the NTS [3], 2 of the 12 projects approved for the NTS expansion of this area were declared deserts [3, 17]; these projects would allow a better performance, eliminate restrictions and also allows greater flexibility in the operation, decreasing the final price of electricity [18].

To encourage investment in the sector, increase the expansion of the NTS, improve reliability and intensify the participation of more companies, it was proposed to change the regulation that defines the remuneration of the transmission activity. The objective of the research is to make a comparison between resolutions CREG 011 of 2009 and CREG 178 of 2014, which will allow identifying the technical and economic implications it could have for the electricity market in Colombia, and specifically for companies in the transmission sector. 


\section{Materials and methods}

\subsection{Regulation of electricity in Colombia}

The electricity sector is governed by Law 143 of 1994 [12] and Law 142 of 1994 [14] because it is a public service; CREG is the entity in charge of regulation, it must establish new formulas for tariff structures to the end-users bills; concepts such as generation, transmission, distribution and commercialization. This regulation should look for a value that allows companies to ensure adequate compensation, improve the reliability of the service and be accessible to users [19]; these tariff formulas are valid for 5 years, once this period expires, they will remain valid until a new methodology is established [14]. The price of electricity in Colombia is structured by Resolution CREG 119 of 2007, where the following charges are collected:

$$
C U_{v}=G+T+D+C_{v}+P R+R
$$

At where, $C U_{v}$ is the unit cost of one $\mathrm{kWh}(\$ / \mathrm{kWh}) ; G$ is the purchase cost of electricity produced by the generation plants $(\$ / \mathrm{kWh}) ; T$ is the cost per use of the NTS $(\$ / \mathrm{kWh}) ; D$ is cost for use of the Distribution System $(\$ / \mathrm{kWh}) ; C$ is the energy trading profit $(\$ / \mathrm{kWh})$ and the following charges are for the reliable and safe operation of the electric power system, $P R$ is the cost of energy losses due to the operation of the electric power system $(\$ / \mathrm{kWh})$; and $R$ is the cost due to the restrictions planned to improve the reliability of the service $(\$ / \mathrm{kWh})$.

Each component has its methodology to determine the value, for the case of transmission, Resolution CREG 011 of 2009 is used, where the installed equipments and the expense associated with the Administration, Operation and Maintenance (AOM) of the assets is remunerated; however, the growth of the networks has not increased as expected, to overcome this drawback, CREG proposes to change the methodology with Resolution CREG 178 of 2014, in order to optimize costs and encourage investors.

UPME is the entity responsibility for designing the expansion plans of the NTS [20], and it is advised by the Comité Asesor de Planeamiento de la Transmisión (CAPT), Transmission Planning Advisory Committee, to establish the most efficient strategies according to the requirements of the demand. A model is used to simulate the operation of the electric power system under different scenarios, which allows identifying problems that affect the quality and reliability of the service, and verify the performance of the equipment; the results allow the design of strategies such as the repowering of the infrastructure, installation of backup equipment, installation of new equipment for the expansion of the electrical system [21]. The projects are evaluated to determine the technical and economic feasibility; then they are offered through competitive bidding processes, and according to the execution priority their planning horizon is determined, long term (15 years), medium term (10 years) and short term (5 years) [3].

\subsection{Methods of incentive regulation for transmission projects}

Transmission activity is established as a natural monopoly [7], and regulation is essential to set an optimal price [7]; this activity can be developed under three types of systems: the first, a centralized and regulated approach, the second analyzes market signals and a decentralized approach and the third is a hybrid of the previous mechanisms [21]; regulated systems do not create sufficient incentives for their expansion while market-based models do not fully remunerate the costs [7].

There are different methods to incentive the activity of transmission, each having advantages and disadvantages with regard to the agents and the market [22]. In Table 1 shows some methods.

Table 1. Methods of incentive regulation

\begin{tabular}{|c|c|}
\hline Method & Remarks \\
\hline Price Cap & $\begin{array}{l}\text { It allows the regulator to impose a price control on the } \\
\text { regulated for a period of time; the income of the national } \\
\text { transmitter will be independent of the demand and only } \\
\text { depends on the investments made. } \\
\text { It encourages productive efficiency due to reduce } \\
\text { historical and AOM costs. } \\
\text { It includes a measure of inflation and compensation, } \\
\text { restricting the increase in prices. } \\
\text { This method allows to avoid or eliminate government } \\
\text { subsidies. }\end{array}$ \\
\hline $\begin{array}{l}\text { Revenue } \\
\text { Cap } \\
\text { Regulation }\end{array}$ & $\begin{array}{l}\text { The income of the company is limited and adjusted } \\
\text { according to an efficiency factor. } \\
\text { It ensures the return of investment and profit. } \\
\text { It provides incentives to encourage investment in } \\
\text { electric assets. } \\
\text { It is sensitive to inflation, causing fluctuations in market } \\
\text { prices to increase. }\end{array}$ \\
\hline $\begin{array}{c}\text { Average } \\
\text { Revenue } \\
\text { Regulation }\end{array}$ & $\begin{array}{l}\text { It set an average rate and the annual income should not } \\
\text { exceed the maximum income. } \\
\text { It improves the surplus due to the increase of the } \\
\text { transmission capacity. } \\
\text { To calculate the price index, it is only necessary to know } \\
\text { the demand, an incentive is provided to reduce costs. }\end{array}$ \\
\hline $\begin{array}{c}\text { Yardstick } \\
\text { Competition }\end{array}$ & $\begin{array}{l}\text { It compare the performance of a company against } \\
\text { similar companies in the sector, which allows improving } \\
\text { the efficiency of the system. } \\
\text { Companies receive an incentive for the implementation } \\
\text { of new technologies. } \\
\text { The competition is given through a "shadow company" } \\
\text { that is built from the costs of the group of companies. }\end{array}$ \\
\hline
\end{tabular}

\subsection{Weighted Average Cost of Capital (WACC)}

The WACC is the weighted average rate of return required by those who provide capital, also called the discount rate or the cost of capital [33], it is used in companies to determine the economic viability of expansion opportunities [34]. Through Resolution CREG 083 of 2008, this method is approved for the calculation of the rate of return. The equation used to calculate the WACC is (2).

$$
W A C C_{a . i .}=w_{d} r_{d}+\frac{w_{e} r_{e}}{(1-\tau)}
$$

At where; $w_{d}$ is the cost of debt, ratio of debt to total assets $40 \% ; r_{d}$ is the cost of debt; $w_{e}$ is the participation of own capital, proportion of own capital versus total assets $60 \% ; r_{e}$ is the cost of own capital or equity; and $\tau$ is the tax rate. CREG uses the rate of return before tax, to do not incur in financial decisions of the companies, the value of this rate is $11.50 \%$ [35].

\subsection{Legal framework for the remuneration of the transmission activity.}

The current resolution and the proposed resolution for the remuneration of the transmission activity established by CREG are detailed.

\subsubsection{Resolution CREG 011 of 2009}

The transmission activity is paid by the Revenue Cap Regulation method, the annual income for each National 
Transmitter (NT) is calculated with equation (3), and it is applied to the existing electricity transport assets that operate at equal or higher voltages at $220 \mathrm{kV}$; taking into account the construction units valued at efficient cost of replacement, the recognition of non-electric assets, administration, operation and maintenance (AOM) expenses and the recognition of land for the constructive units (UC) of substations.

$$
\begin{aligned}
& I A T_{j}=C A E A_{j}(1+\% A N E)+V A O M_{j}+C A E T_{j}+ \\
& C A E S_{j}-O l_{j}
\end{aligned}
$$

At where; $I A T_{j}$ is the annual income of the NT (\$); CAEA is the annual equivalent cost of the electric asset valued at replacement cost $(\$) ; \% A N E$ ANE is the percentage recognized for non-electric assets; $V A O M_{j}$ is the value of AOM expenses (\$); $C A E T_{j}$ is the annual equivalent cost of land for NT (\$); $C A E S_{j}$ is the annual equivalent cost of easements for NT (\$); and $O l_{j}$ are other income from the exploitation of the assets remunerated through charges for use in activities other than the transmission of electric power.

$$
\begin{aligned}
& C A E A_{j}=\sum_{i=1}^{U R_{j}}\left(N U C_{i} * C U_{i} * P U_{j, i}(1-\right. \\
& \left.\left.R P P_{j, i}\right) \frac{T R}{1-(1+T R)^{-V U_{i}}}\right)
\end{aligned}
$$

At where; $C A E A_{j}$ is the annual equivalent cost of the electric asset valued at replacement cost $(\$) ; N U C_{i}$ is the amount of each UC reported by the NT; $C U_{i}$ is the unit cost of each $\mathrm{UC} ; P U_{j, i}$ is the percentage paid to the NT, through charges for the use of $\mathrm{UC} ; R P P_{j, i}$ is the fraction that is calculated from the part of the UC value that should not be included in the calculation of the tariff, with respect to the total value of the UC; TR is the rate of return; y $V U_{i}$ is the useful life of the UC.

$$
C A E T_{j}=\% R \sum_{i=1}^{a_{j}}\left(A T U C_{i}\right)\left(V C T_{s}\right)
$$

At where; $C A E T_{j}$ is the annual equivalent cost of land for $\mathrm{NT}(\$) ; \% R$ is the value equal to the real cost of debt included in the rate of return (TR); $A T U C_{i}$ is the area of the $\mathrm{UC} ; V C T_{s}$ is the cadastral value of the square meter of the substation area, where the UC is located; and $U R_{j}$ is the total number of $\mathrm{UC}$ reported by the NT.

\subsubsection{Resolution CREG 178 of 2014}

This is the proposal for the change of Resolution CREG 011 of 2009 , it is in consultation with industrialists and other stakeholders. Its objectives are to encourage the replacement of assets, improve the quality of service, achieve efficient AOM expenses, allow investment stability and obtain competitive rates [36, 37]. The annual income for NT is calculated according to (6).

$$
I A T_{j, t}=I A A_{j, t}+I A A O M_{j, t}+I A I N C_{j, t}-O l_{j}
$$

At where; $I A T_{j, t}$ is the annual income of the NT in the year $\mathrm{t} ; I A A_{j, t}$ is the annual income from investment in NT assets in the year $\mathrm{t} ; \operatorname{IAAOM}_{j, t}$ is the annual incentive income of AOM of NT in the year $\mathrm{t} ; I I I N C_{j, t}$ is the annual incentive income of the NT in the year $\mathrm{t}$; and $O l_{j}$ are income from the exploitation of the assets remunerated through charges for use in activities other than the transmission of electricity.
The expression (7) is used to calculate the annual investment income of the NT:

$$
I A A_{j, t}=B R A_{j, t} * r+R C_{j, t}+B R T_{j, t}
$$

At where; $I A A_{j, t}$ is the annual investment income of the $\mathrm{NT} ; B R A_{j, t}$ is the NT regulatory asset base; $r$ is the rate of return; $R C_{j, t}$ is the recognized capital recovery for the assets remunerated in the NT regulatory base; and $B R T_{j, t}$ is the regulatory basis of the NT land.

\section{Results}

\subsubsection{Comparison of resolutions CREG 011 of 2009 and CREG 178 of 2014.}

The change of scheme encourages companies to invest in the replacement and repowering of their electric assets, through incentives and penalties depending on their efficiency in investment and operation; seeking to achieve a reduction in costs, improve the quality of service and stimulate investment, this will lead to a more competitive and fair price for users [38].

The efficiency is determine by the investment value of the company in comparison with the base value defined by the CREG and by the quality of the service according to the hours of availability, CREG fixes the maximum number of hours of unavailability. This will encourage companies to carry out strategic planning to improve their investments and preventive and corrective maintenance plans. Table 2 presents a comparison between the resolutions CREG 011 of 2009 and CREG 178 of 2014, the change of methodology will lead to an optimization of the resources looking for the efficiency in investment and operation of their electrical assets.

\subsubsection{Economic assessment of resolutions CREG 011 of 2009 and CREG 178 of 2014.}

It is consider the project STN06-2013 (Flores, Caracolí, Sabanalarga) developed by Intercolombia [38] to make an economic assessment with the resolutions, this project contains the assembly of the Caracolí Electrical Substation (ES) at $220 \mathrm{kV}$, the extension of Termoflores ES, the extension of Sabanalarga ES and the construction of $58 \mathrm{~km}$ of overhead lines and $5 \mathrm{~km}$ of underground lines; it has a value of 61.28 MMUSD, this plan will improve the reliability of the service in the region, mainly in the cities of Barranquilla, Soledad, Malambo and Sabanalarga. With equations (2) to (7) assessed it the behavior of NT income, using $14.27 \%$ as the value of the WACC before tax expressed in dollars. Figure 1 presents the behavior of the CAEA, this variable represents $75.36 \%$ of the annual income of the NT, when the rate of return varies $0.27 \%$.

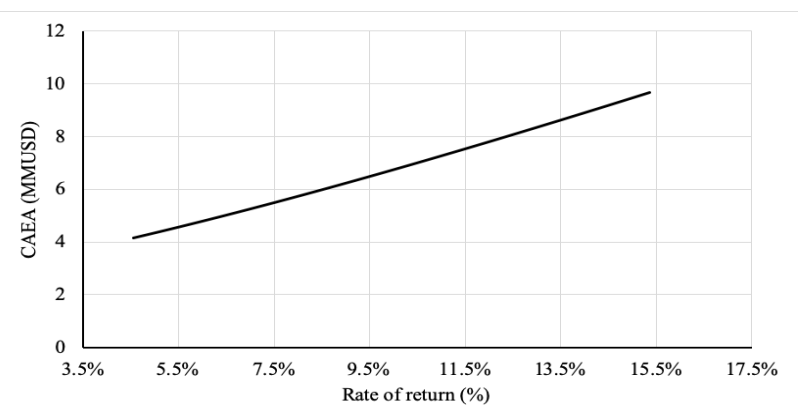

Fig. 1. The behavior of CAEA. 
Figure 1 indicates that the CAEA has an increasing behavior as the value of the rate of return increases; a change of $0.27 \%$ in the rate of return will represent a change in the CAEA of $2.14 \%$ (6.79 MMUSD) in the equivalent annual cost; Indicating that the rate of return is of great importance for the annual income of the agents.

Resolution CREG 059 of 2017 updates the electric assets base of ISA, this indicates the total amount of investments made by this company and is identified as the Asset Replacement Cost; with this value, the annual income of this company is evaluated using the methodology of resolution CREG 011 of 2009 and resolution CREG 178 of 2014.

The following consideration are taken, it is consider an increase of 5\% of the Regulatory Base of New Electric Assets, it remain constant the cost of the Regulatory Base of Electric Assets that come out of operation and it is considered a useful life of 45 years, there is no depreciation of the assets at the beginning, because all the assets are new; this last aspect is the most important one change in the new regulatory framework. Figure 2 shows the behavior of the annual income received.

Table 2. Comparison between the resolutions CREG 011 of 2009 and CREG 178 of 2014.

\begin{tabular}{c|l|l}
\hline Items & \multicolumn{1}{|c|}{ Resolution CREG 011 of 2009 } & \multicolumn{1}{c}{ Resolution CREG 178 of 2014 } \\
\hline $\begin{array}{c}\text { Asset valuation } \\
\text { method }\end{array}$ & $\begin{array}{l}\text { Revenue Cap Regulation } \\
\text { It does not take into account the useful life of the } \\
\text { electric asset and they are remunerated as new. }\end{array}$ & $\begin{array}{l}\text { Revenue Cap Regulation } \\
\text { It takes into account the useful life and remnant of } \\
\text { the assets. }\end{array}$ \\
\hline AOM & $\begin{array}{l}\text { The AOM costs are those recognized and spent by } \\
\text { each National Transmitter }\end{array}$ & $\begin{array}{l}\text { The AOM costs are those recognized from the } \\
\text { investments and incentives received from the } \\
\text { National Transmitter. }\end{array}$ \\
\hline $\begin{array}{c}\text { Investments } \\
\text { assets }\end{array}$ & $\begin{array}{l}\text { A new value of the investments is obtained every } \\
\text { five years. }\end{array}$ & $\begin{array}{l}\text { A new value of the investments is obtained every } \\
\text { year. }\end{array}$ \\
\hline $\begin{array}{c}\text { Puality of } \\
\text { service }\end{array}$ & $\begin{array}{l}\text { The quality indexes are obtained from the historical } \\
\text { information of the service. } \\
\text { There is a maximum value of unavailability. } \\
\text { When the National Transmitter exceeds the } \\
\text { maximum unavailability value, it must include } \\
\text { compensation, which is reflected in the energy } \\
\text { service bill. }\end{array}$ & $\begin{array}{l}\text { The quality indexes are obtained from the efficient } \\
\text { data of the service. } \\
\text { It is proposed to modify the maximum allowed } \\
\text { annual hours of unavailability (decrease). } \\
\text { When the National Transmitter exceeds the } \\
\text { maximum unavailability value, it must include } \\
\text { compensation, which is reflected in the energy } \\
\text { service bill. }\end{array}$ \\
\hline
\end{tabular}

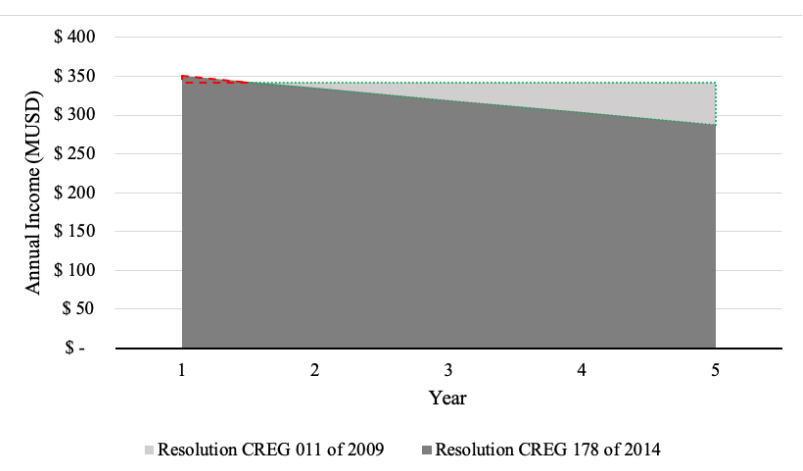

Fig. 2. Comparison of Annual Income according to resolutions CREG 011 of 2009 and CREG 178 of 2014

Figure 2 presents the annual income of ISA calculated according to resolution CREG 011 of 2009 (light gray) and resolution CREG 178 of 2014 (dark gray); with the implementation of the new methodology there will be a better management of costs due to the consideration of the useful life of the assets and the return of the investments made by each agent is guaranteed.

For the first year with the proposed methodology, the agent will receive an increase in their income of $2.40 \%$ or USD 8,432,570, represented by the dashed red line; however, at 1.53 years, your income will be equal to the current resolution of USD 342,330,813, for year 5 total revenue will decrease by $6.72 \%$ or USD $115,064,843$, represented by the green dotted line.
The difference in the agent's annual income due to the change in the regulation is USD $106,632,273$, mainly due to the consideration of the depreciation of the installed assets; this amount would represent a decrease in the contributions that users must make in the payment of their electricity bill in the concept of transmission of equation (1).

Annual income also depends on the declaration of expenses executed and declared, according to these values may access an incentive or a penalty due to compliance, this is represented by a percentage; the agents must implement alternatives to generate higher revenues such as the replacement of electrical assets and increasing the capacity of energy transport [39]. The quality of the service will be evaluated according to the number of hours in unavailability, amount established by the CREG; the SAIDI indicator (System Average Interruption Duration Indicator) is taken to measure the average duration per user of service interruptions [40].

\section{Conclusions}

The resolution proposal by CREG has the necessary mechanisms to encourage companies to invest in their electric assets and make a more efficient use of AOM expenses, to achieve competitive rates and sustainability for companies.

Table 2 presents the most important differences between the two resolutions, there will be an evaluation of the performance using the SAIFI indicator and the depreciation of the assets will be taken into account, guaranteeing remuneration for the companies and a fairer charge for endusers. 
The value considered for the rate of return will be the determinant in the increases or decreases in the annual income of each company in the transmission sector; this rate takes into account the capital invested according to the risk of the activity.

This new proposal will encourage companies to invest frequently in their electric assets, to achieve greater increase in the concepts of annual investment income. In order to obtain a greater benefit, the efficiency and quality of the service provided must be improved.

The economic evaluation made it possible to establish the Annual Income of ISA, and to determine the monetary and percentage changes in concepts of Annual Income, presenting an increase of $2.40 \%$ for the first year and a decrease of $6.72 \%$ for following years. This difference represents a saving to the end-users of the electricity service; this decrease in revenues should not be consider as losses for companies, because by law the return on investment of agents and a payment based on the risk of the activity is guaranteed, it should be understood that it is a mechanism to obtain real and competitive rates.

This is an Open Access article distributed under the terms of the Creative Commons Attribution License

\section{References}

[1] H. Rudnick and J. Zolezzi, "Electric sector deregulation and restructuring in Latin America: lessons to be learnt and possible ways forward," IEE Proceedings-Generation, Transmission and Distribution, vol. 148, no. 2, pp. 180-184, 2001.

[2] N. Abdul Wahab, S. Musa, R. Ahmed and H. Bt Rusli, "Optimisation techniques for location of flexible AC transmission system devices in power systems," Journal of Engineering Science and Technology Review, vol. 6, no. 5, pp. 61-66, 2013.

[3] UPME, "Plan de Expansión de Referencia Generación Transmisión 2017 - 2031," Ministerio de Minas y Energía, Bogotá D.C, 2017.

[4] UPME, "Quiénes Somos," March 2019. [Online]. Available: http://www1.upme.gov.co/Entornoinstitucional/NuestraEntidad /Paginas/Quienes-Somos.aspx.

[5] XM, "Líneas de Transmisión por Agentes Operadores," Parámetros Técnicos del SIN (PARATEC), Medellín, 2018.

[6] Interconexión Eléctrica SA - ESP, "Línea de Tiempo Nuestra Historia ISA," [Online]. Available: http://www.isa.co/es/nuestra-compania/Paginas/quienessomos/historia.aspx. [Accessed 1 March 2019].

[7] J. D. Molina and H. Rudnick, "Transmission of Electric Energy: a Bibliographic Review," IEEE Latin America Transactions, vol. 8, no. 3, pp. 245-258, 2010.

[8] XM Filial de ISA, "Estructura del Mercado," [Online]. Available: https://www.xm.com.co/Paginas/Mercado-deenergia/Agentes-del-mercado.aspx. [Accessed 02 March 2019].

[9] ISA, "ISA Intercolombia," 2019. [Online]. Available: http://www.isa.co/es/Paginas/paises/colombia.aspx.

[10] CREG, "Resolución 001 de 1994," Ministerio de Minas y Energía, Bogotá D.C., 1994.

[11] C. O. Zambrano Pérez, Análisis de mecanismos de mercado para la remuneración y asignación de capacidad de transmisión en el mercado eléctrico colombiano, Medellín, Colombia: Universidad Nacional de Colombia, 2013.

[12] Congreso de Colombia, "Ley 143," Bogotá DC, 1994.

[13] Resolución No. 085, 2002.

[14] Congreso de Colombia, "Ley 142," Bogotá DC, 1994

[15] D. M. López González and S. Z. Tabares Álvarez, Estudio De La Tasa De Remuneración Del Sistema De Transmisión Nacional De Enegía Eléctrica En Colombia, Medellín: Universidad EAFIT - Escuela De Economía Y Finanzas, 2014.

[16] L. F. Moreno, "El Modelo De Libre Competencia: El Caso De Colombia," in Regulación Del Mercado De Energía Eléctrica En América Latina: La convergencia entre libre competencia e intervención estatal, Bogotá, Universidad Externado De Colombia, 2012, pp. 93-230.

[17] UPME, "Sistema De Información Minero Energético Colombiano," [Online]. Available: http://sig.simec.gov.co/GeoPortal/Mapas/Mapas. [Accessed 02 March 2018].

[18] UPME, "Plan de Expansión de Referencia Generación Transmision 2016 - 2030," Ministerio de Minas y Energía, Bogotá D.C., 2016.

[19] J. C. Giacomini, N. K. Santos and A. d. R. Abaide, "Expansion planning of electric power distribution systems under the paradigm of price cap regulation," 2013 10th International Conference on the European Energy Market (EEM), IEEE, pp. $1-8,2013$.

[20] Congreso de Colombia, Decreto No. 1258 de 2013, Bogotá D.C.: Ministerio de Minas y Energía, 2013.

[21] J. D. Molina and H. Rudnick, "The challenges of transmission asset in Colombia: Planning and acceptability of expansion projects," IEEE PESTransmission \& Distribution Conference and Exposition - Latin America, pp. 1-5, 2014.

[22] C. Zambrano, Y. Olaya and J. Velásquez, "Mechanisms for remunerating electricity transmission capacity," IEEE LATIN AMERICA TRANSACTIONS, vol. 13, no. 9, pp. 2955-2960, 2015.

[23] A. Fusch, «La inflación mundial, originada por los países desarrollados,» El País, https://elpais.com/diario/1978/08/01/economia/270770403_850 215.html, 1 Agosto 1978.

[24] M. Armstrong, S. Cowan and J. Vickers, Regulatory reform: economic analysis and British experience, MIT press., 1994.

[25] M. F. Canoy, F. A. Hindriks and B. A. Vollaard, "Yardstick Competition: Theory, Design, and Practice," CPB Netherlands Bureau for Economic Policy Analysis, 2000.

[26] G. Rothwell and T. Gómez, Electricity Economics: Regulation and Deregulation, IEEE Power Engineering Society, 2003.

[27] E. C. Arias and J. V. Cadavid, "La regulación económica de las distribución de la energía eléctrica," Ecos de Economía: A Latin American Journal of Applied Economics, vol. 8, no. 18, pp. 99139, 2004.

[28] M. A. Jamison, "Regulation: Price Cap and Revenue Cap," Encyclopedia of Energy Engineering and Technology, vol. 3, pp. 1245-51, 2007.

[29] M. Tanaka, "Extended Price Cap Machanism for Efficient Transmission Expansion under Nodal Pricing," Networjs and Spatial Economics, vol. 7, pp. 257-275, 2007.

[30] I. Matsukawa, "The effects of average revenue regulation on electricity transmission investment and pricing," Energy Economics, vol. 30, no. 3, pp. 696-714, 2008.

[31] H. Khalfallah, "An assessment of Incentive Regulation in electricity networks: The story so far.," Cahier de recherche EDDEN, vol. 9, 2013.

[32] A. Campbell, "Cap prices or cap revenues? The dilemma of electric utility networks," Energy Economics, vol. 74, pp. 802812, 2018.

[33] S. Ruiz Campo and S. Zuning-Jara, "Reviewing capital costo estimationes in aquacultura," Aquaculture Economincs and Management, vol. 22, no. 1, pp. 72-93, 2018.

[34] S. Fonseca, "The Impact of WACC Calculation in the Price Cap Regukation Results: The Colombian Case," IEEE Power Engineering Society General Meeting, pp. 1-3, 2007.

[35] CREG, "Resolución 083 de 2008," Ministerio de Minas y Energía, Bogotá D.C., 2008.

[36] CREG, "Metodología para remunerar la transmisión de energía eléctrica," Nuevas Ediciones Ltda, Bogotá D.C., 2014.

[37] CREG, "Metodología de remuneración de la actividad de transmisión de energía eléctrica para el periodo tarifario 20152019," Documento CREG 098 de 2014, Bogotá D.C., 2014. 
Andrés Andrade-Becerra, Sergio Marenco-Rua, John-William Grimaldo-Guerrero, Eliana-Maria Noriega-Angarita and Jorge-Ivan SilvaOrtega/Journal of Engineering Science and Technology Review 12 (6) (2019) 11 - 16

[38] P. L. Joskow, "Incentive Regulation in Theory and Practice: Electricity Distribution and Transmission Networks," in Economic Regulation and Its Reform: What Have We Learned?, Masachusett, The National Bureau of Economic Research, 2005, pp. 291-344.
[39] T. Kwa-Sur, "Assessment and enhancement of the utilization of electric power transmission lines," Proceedings of SOUTHEASTCON '96, IEEE, pp. 618-625, 1996.

[40] Superintendencia de Servicios Públicos Domiciliarios, "Diagnóstico de la Calidad del Servicio de Energía Eléctrica en Colombia," Superservicios, Bogotá D.C., 2016. 